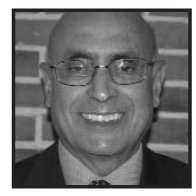

\title{
Commentary:
}

\section{How and Why Does Poetry Matter? And What Do We Do About That?}

\author{
Patrick Dias, McGill University
}

\section{ABSTRACT}

While there is a long and widely held belief that poetry matters and is a necessary component of the school curriculum, such convictions are at odds with the way poetry is taught and the general antipathy that students, especially in secondary school, hold towards it. Such disregard is well established among most school teachers who have been similarly schooled and consequently distrust their own competence as readers of poetry and unwittingly perpetuate such insecurity. Teachers need to act with some urgency to determine why poetry is such a valuable cultural and social good, and consider the easily accessible means by which poetry can be enthusiastically embraced by their pupils.

ome readers may wonder why there is any need to defend the status of poetry as an essential component of the English curriculum from early childhood to post-secondary education. Most readers may have serious misgivings about my assertion that poetry receives merely token recognition in school programs and that it is in fact dying of neglect. Yes, it is true that through the long history of teaching poetry in school, the value of poetry and its place in the curriculum has never been seriously disputed, and yet? And yet in many schools hardly any poetry is read and/or given serious study.

While we may profess the importance of poetry as quite likely the sustaining genre of our literary tradition, such acknowledgment does not accord with the 
neglect of poetry in schools. If poetry matters to us, why is that conviction not reflected in the amount of poetry that is offered in our programs and the frequency with which it is offered in our classrooms? How do the ways poetry is taught in schools accord with our convictions about its place in the curriculum. Maybe there is little enthusiasm for poetry among our students and, it follows, a corresponding reluctance on the part of teachers to teach poetry. Surely, we need to repair the disconnect between our enthusiasm for poetry and the lack of reciprocity on the other side of the desk.

On initial inquiry into the current situation in schools, it appears that the possibility of such repair holds little promise. In England, when a large number of teachers were polled to provide a sample list of the poems they usually used in their classrooms, the titles they listed were not significantly different from poems I and most other teachers had used some decades ago. Shocking but not surprising because superannuated anthologies resident in school book-cupboards provide easily accessible poems; and shouldn't teachers casting around for poems to teach turn to the ones they know so well, however tired and stale they might be? And familiar also were the themes these poems were grouped under: Nature, War, Children, and Animals. Not that more recent poets and their poetry had not flowed into the curriculum. Among later additions were Seamus Heaney and Ted Hughes, quite likely because of a very popular anthology Rattlebag edited by the two poets and first published in 1982. But what is significant as well as discouraging is that the teachers listing poems they had probably met during their own schooling suggests that most of them had not considered it worth their while to enlarge and rejuvenate their repertoire of the poems that might appeal to their students (OFSTED, 2007).

Just as established and even more disconcerting are the suggestions for classroom practice offered by curriculum planners and educational publishers. If I can generalize from a sampling of their institutional websites, typical approaches to teaching poetry seem not to have altered ever since poetry was offered in school textbooks in the fifties and early sixties. Introduce the poem with a brief biography of the poet, thereby signalling what the students may expect to read and identify in the poem; then introduce the class to some of the specific formal features that the poem displays, such as, depending on the grade level, rhyme schemes, meter, relevant figures of speech. A particular goal is for students to arrive at the theme of the poem by, as one guide puts it, a process of induction. The induction is drawn out through a series of questions that are meant to lead to an already determined theme. Sequences include a brief biographical introduction, an examination of formal features (ballads or sonnets, for instance) and viewing a specific poem in terms of those 
features, and if and how the poet may have deviated from the form and to what effect. All these several points of recognition are directed towards enhancing understanding of the poem and appreciation of how the poem works. In most cases identifying "the theme" of the poem is also recognition of "the universal truth" implicit in its statement.

What I have described as typical procedures that I discovered from my sampling of curricular practices over the last decade is no more than going full circle and reviving what had been sloughed off over four decades earlier. The sequence moving from parts to wholes contradicts our typical stance before a work of art, where we apprehend (there's a physicality about that word that goes beyond "comprehend") the whole, and then cast about again as we read the poem recognizing those lines and those phrases which have drawn our attention and compose the larger picture we are constructing with the aid of those signs. But it is not a step-by-step process; it can happen or be intuited in an instance. Instead of following a path from basic information (difficult words, references, background information) to the key issues the poem addresses, readers need to be communing with the poem as a whole, sounding and hearing the words, attentive to the feelings they stir in us, the images that take us unawares. If we are working in small groups, as I prefer to do, my students read the poem aloud a few times to get their bearings; they draw from a variety of observations and slowly the composition takes shape and identity. This is not a process seemingly laid out for unimaginative teachers, the yellow brick road that takes students to "the theme." I must say that one formulates a theme at the certain risk of reductiveness. The very pithiness of a poem is its virtue; not a word or an image in excess; so why simplify or reduce the poem and have our neophyte readers of poetry lose the complex whole and force of the poem?

It is at this stage of realizing ("understanding" seems passive by comparison) or grasping the poem, that we can now speak of the actual images (the metaphors, comparisons, the verbal play), where these figures of speech find their force and meaning.

I had begun by asking how and why poetry matters, and postponed exploring that question simply because the poem's mattering, more often than not, is compromised or impeded by the countervailing interventions (all well intentioned) of the teacher. That is another way of saying poetry cannot matter when the reader's response is filtered through or directed by the teacher's directive questions or comments. If the poem is to matter, the reader(s) must be engaged by the poem, actively involved in remaking that poem. That engagement is a developing outcome of being 
attentive to and having confidence in one's own resources as a reader. I have described at some length in an earlier issue of LEARNing Landscapes how readers at all levels can be engaged by poetry and become confident and articulate readers (Dias, 2009). Reading and responding to a poem is a creative act, and I cannot emphasize this enough, it is enabled as a creative act only when one is reading for oneself, registering whatever feelings, associations, and memories the poems evoke, and is not inhibited by the guiding questions of the teacher (even with the best will in the world) or by the anticipated pattern of questions to follow.

Imagine how off-putting it would be if you were listening attentively to a piece of music and at the same time had to keep your mind on directions as to how you must attend and what you must attend to as you listen. Consider also one of those audio guides available in art galleries, which give a running commentary on what we are about to see and how we must look at it. There are two aspects to this attending to music, to visual art, and to a literary work. One is that we need to be engaged, and the other, that we need to trust ourselves as listeners, viewers, and readers. This involves a process of familiarization where poems become familiar objects, where they are read without the injunction that they must be fully and clearly understood, where one learns to set a poem aside to return to, if one wishes, at a more propitious time. Susanne K. Langer, a philosopher who has theorized about art and the place of art in our society has written, "The entire qualification one must have for understanding art is responsiveness" (1953, p. 396). Perhaps cultivating responsiveness is the agenda we must commit ourselves to if poetry is to matter.

The title I had set to guide my argument engaged two questions: "How and why does poetry matter?" and "What do we do about it?" To even attempt cogent answers would be far too presumptuous, given that the questions can apply to other art forms as well. I proposed the questions simply because poetry performs an important function in our society and neglecting poetry is denying a value to our developing young. The importance of poetry to our daily living is trenchantly caught in Wallace Stevens' "Poetry is a response to the daily necessity of getting the world right" (Introduction to Wallace Stevens: Selected Poems, edited by John N. Serio. New York: Alfred A. Knopf, 2009, p. xiii). In my own middle age, as I watched my children rollick in the pile of leaves I had raked, I felt the sadness of Gerard Manley Hopkins' "Spring and Fall" and knew what ailed me and that I had to move on. I know also that young people can contemplate such reality and get "the world right," particularly against the draw of escapist fantasy. 


\section{So How and Why Does Poetry Matter}

I keep returning to these questions about the importance of poetry simply because I believe there is a lack of correspondence between public assertions about poetry as a cultural value and how poetry is generally regarded and taught in schools. Once again, Susanne Langer is helpful. In "The cultural importance of the arts," an article she wrote for the inaugural issue of the Journal of Aesthetic Education, Spring, 1966, she makes several key observations; I need to refer to just two of them:

The primary function of art is to objectify feeling so we can contemplate and understand it. (p. 9) ... As soon as the natural forms of subjective experience are abstracted to the point of symbolic presentation, we can use those forms to imagine feeling and understand its nature. (p. 11)

Towards the conclusion of her essay, we come to:

Wherever art takes a motif from actuality -- a flowering branch, a bit of landscape, a historic event or a personal memory, any model or theme from life -- it transforms it into a piece of imagination, and imbues its image with artistic vitality. The result is an impregnation of ordinary reality with the significance of created form. This is the subjectification of nature, that makes reality itself a symbol of life and feeling. (italics mine)

The arts objectify subjective reality, and subjectify outward experience of nature. Art education is the education of feeling, and a society that neglects it gives itself up to formless emotion. Bad art is corruption of feeling. This is a large factor in the irrationalism which dictators and demagogues exploit. (p. 12)

Objectifying "feeling so we can contemplate and understand it" resonates with Stevens' "the daily necessity of getting the world right." But the rest of Langer's assertion helps us understand exactly how poetry can work for us and what we ought to expect poetry to do for us and our students. In the end, contemplating the small group discussion procedure I have promoted, I know that students know what they know not because I have told them or showed them or guided their inquiring, but because they have been engaged and mystified and are curious and therefore have looked hard because they know they are accountable to one another and to the other groups and certainly not to the teacher, who can be assured that what has been realized by the students has been realized (you may want to call it learning) solely by 
their speaking and listening to one another because they have felt the need to know. So the student can truly say, as one did with some frustration to a seemingly sceptical me who was devil-advocating for returning "teaching" to the teacher, "This way I know it for myself!"

So how do we translate our love of poetry, our valuing of poetry into the kind of teaching that enables students to develop a sensibility, so that their feelings can be educated, so that they can discover over and over again in their own lives, from their experiences, "how ordinary reality can be impregnated with the significance of created form." So that their perceiving, their recognitions are fresh and not second-hand. So they can turn away from the easy clichés that encapsulate reality into pastiches of cliché-ridden phrases. Perhaps it is not easy to live with such heightened sensibility so much so that politicians and advertisers and radio and TV hosts grate on our ears, and even more so because they have themselves become blind and deaf to their own larding-over reality. So we turn to a poet for insight:

Go, said the bird, for the leaves were full of children,

Hidden excitedly, containing laughter.

Go, go, go, said the bird: human kind

Cannot bear very much reality.

From:T.S. Eliot (1963), Burnt Norton, Four Quartets

\section{References}

Dias, P. (2009). Life-long readers of poetry? Why not. LEARNing Landscapes, 3(1), 123-138.

Eliot, T.S. (1963). Burnt Norton, Four Quartets in Collected Poems 1909-1962. London: Faber and Faber.

Heaney, S., \& Hughes, T. (Eds.). (1982). The Rattlebag. An anthology of poetry. London: Faber and Faber.

Langer, S.K. (1953). Feeling and form. New York: Charles Scribner's Sons.
Langer, S.K. (1966). The cultural importance of the arts. Journal of Aesthetic Education, 1(1), 5-12.

OFSTED (2007). Poetry in schools: A survey of practice, 2006/2007. London: HMI.

Serio, J.N. (Ed.). (2009). Wallace Stevens: Selected poems. Introduction. New York: Alfred A Knopf. 


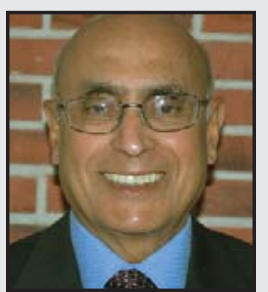

Patrick Dias is Emeritus Professor of Education, McGill University, Montreal. He has been variously, Visiting Scholar at Wolfson College, Cambridge and part-time Lecturer, Department of Education, Cambridge University, Visiting Professor at UNB, UBC, and most recently at Carleton University, Ottawa. He also served for several years as consultant on curriculum development to the Quebec Ministry of Education. At McGill, he founded the Centre for the Study and Teaching of Writing and was its director for 12 years. He has lectured widely across Canada, the U.S., and in the U.K. He has researched response to literature among children, adolescents, and adults and the development of writing abilities in school and in workplace settings, publishing six books and several articles in these areas. 